\title{
Mechanisms of arginine-induced increase in cytosolic calcium concentration in the beta-cell line NIT-1
}

\author{
A J. Weinhaus ${ }^{1}$, P. Poronnik ${ }^{3}$, B .E . Tuch' ${ }^{2}$, D. I. C ook \\ ${ }^{1}$ Department of Medicine, University of Sydney, Sydney, Australia \\ ${ }^{2}$ Department of Endocrinology, Prince of Wales Hospital, Sydney, Australia \\ ${ }^{3}$ Department of Physiology, University of Sydney, Sydney, Australia
}

Summary The effects of $\mathrm{L}$-arginine and its analogues $\mathrm{N}^{\mathrm{G}}$-nitro-L-arginine, $\mathrm{N}^{\mathrm{G}}$-methyl-L-arginine, L-homoarginine and $\mathrm{D}$-arginine on cytosolic calcium concentration were investigated to characterise the mechanisms of arginine-induced stimulation and to determine if nitric oxide production played a role in this stimulation. NIT-1 cells, a transgenic beta-cell line, were used for this purpose since they release insulin in response to typical beta-cell stimuli. Our data demonstrate that the arginine-induced increase in cytosolic calcium concentration was completely dependent on the influx of extracellular $\mathrm{Ca}^{2+}$ via verapamil-sensitive voltage-activated $\mathrm{Ca}^{2+}$ channels and that arginine stimulation requires the presence of a nutrient in order to cause an increase in cytosolic calcium concentration. The nutrient likely acted by closing the $\mathrm{K}^{+}{ }_{\text {ATP }}$ channels, since its effect could be inhibited by activation of these channels with diazoxide. L-arginine, as well as nitro-arginine and methyl-arginine which are not substrates for the production of nitric oxide, caused similar increases in cytosolic calcium concentration. Non-metabolisable arginine analogues homoarginine and $\mathrm{D}$-arginine also caused increases in the cytosolic calcium concentration although not to the same extent. Insulin secretion was enhanced to the same extent by all analogues of arginine. It can be concluded that the arginine-induced increase in cytosolic calcium concentration in NIT-1 cells is attributable to an electrogenic effect following the transport of arginine leading to depolarisation of the plasma membrane potential, although metabolism of the amino acid itself may also partially contribute to the response. [Diabetologia (1997) 40: 374-382]

Keywords Arginine, $\mathrm{N}^{\mathrm{G}}$-nitro-L-arginine, $\mathrm{N}^{\mathrm{G}}$-methylL-arginine, L-homoarginine, fura-2, intracellular $\mathrm{Ca}^{2+}$ concentration $\left(\left[\mathrm{Ca}^{2+}\right]_{\mathrm{i}}\right)$, NIT-1 cells.
Changes in beta-cell cytosolic calcium concentration $\left(\left[\mathrm{Ca}^{2+}\right]_{\mathrm{i}}\right)$, whether by an influx of extracellular $\mathrm{Ca}^{2+}$ or by release of $\mathrm{Ca}^{2+}$ from intracellular stores, are thought to be the primary trigger for the initiation of insulin secretion [1-4]. Glucose, the major insulin secretagogue, stimulates insulin release by the

Received: 16 October 1996 and in revised form: 24 December 1996

Corresponding author: Dr. D.I. Cook, Department of Physiology (F13), University of Sydney, NSW 2006 Australia A bbreviations: $\left[\mathrm{Ca}^{2+}\right]_{\mathrm{i}}$, Intracellular $\mathrm{Ca}^{2+}$ concentration; Nit$\arg , \mathrm{N}^{5}$-[Nitroaminidino]-L-2,5-diaminopentanoic acid; Me$\arg , \mathrm{N}^{\mathrm{G}}$-methyl-L-arginine ( $\mathrm{N}^{5}$-[Methylamidino]-L-ornithine; $\mathrm{NMDG}^{+}$, N-methyl-D-glucamine; Sin-1, 3-morpholino-syndonimine-hydrochloride; SNP, sodium nitroprusside. production of ATP during its metabolism thus increasing the cytosolic ATP/ADP ratio. This in turn closes the $\mathrm{K}^{+}$ATP channels in the plasma membrane $[5,6]$ leading to the depolarisation of the membrane potential $[7,8]$. This depolarisation causes the opening of the voltage-activated $\mathrm{Ca}^{2+}$ channels, also present in the plasma membrane [9-12], resulting in the influx of $\mathrm{Ca}^{2+}$ into the cell and the subsequent elevation of $\left[\mathrm{Ca}^{2+}\right]_{i}$.

The amino acid arginine causes insulin release from the perfused pancreas, pancreatic explants and perifused islets of the rat as well as from glucose-insensitive human [13] and rat $[14,15]$ fetal beta cells. Arginine also causes an increase in $\left[\mathrm{Ca}^{2+}\right]_{\mathrm{i}}[11,16-$ 18] in beta cells; however, the cellular mechanisms involved in this response are not well understood. 
Several mechanisms for arginine-induced beta-cell stimulation have been proposed. These include the metabolism of L-arginine leading to the formation of ATP $[19,20]$, the generation of nitric oxide [21, 22], and the direct depolarisation of the plasma membrane potential, due to the accumulation of the cationic amino acid [18, 23, 24].

We performed experiments on the NIT-1 insulinoma cell line established from a transgenic mouse [25]. We first characterised the responses of this cell line to arginine and other stimulants of insulin secretion to confirm that its properties were similar to those of other beta cells. We then used the ratiometric fluorescent probe of $\mathrm{Ca}^{2+}$, fura-2, to study the increase in $\left[\mathrm{Ca}^{2+}\right]_{i}$ in response to arginine and arginine analogues to determine the role of nitric oxide production in arginine-induced stimulation of beta cells.

\section{Materials and methods}

M aterials. L-arginine and its analogues $\mathrm{N}^{\mathrm{G}}$-nitro-L-arginine $\left(\mathrm{N}^{5}\right.$-[Nitroaminidino]-L-2,5-diaminopentanoic acid)(nit-arg), $\mathrm{N}^{\mathrm{G}}$-methyl-L-arginine ( $\mathrm{N}^{5}$-[Methylamidino]-L-ornithine $)(\mathrm{me}$ arg), L-homoarginine (2-amino-6-guanidinohexanoic acid), Darginine as well as D,L-glyceraldehyde, N-methyl-D-glucamine $\left(\mathrm{NMDG}^{+}\right)$, verapamil hydrochloride and the disodium salt (grade I) of adenosine $5^{\prime}$-triphosphate (ATP) were purchased from Sigma Chemical Co. (St. Louis, Mo., USA). 3-morpholino-syndonimine-hydrochloride (sin-1) was a generous gift from Pharmaforschung (Frankfurt, Germany). Diazoxide was obtained from Research Biochemicals Incorporated (RBI) (Natick, Mass., USA) and ionomycin from Calbiochem (San Diego, Calif., USA). All chemicals were analytical reagent grade.

NIT-1 cells (passage 90-110) were maintained in culture in antibiotic free, low-glucose $(5.6 \mathrm{mmol} / \mathrm{l})$ DMEM medium (Gibco, Grand Island, N. Y., USA) supplemented with $10 \%$ fetal calf serum at $37^{\circ} \mathrm{C}$ in $5 \% \mathrm{CO}_{2}$ and air. For microfluorometric experiments cells were grown on glass coverslips for 2 days. Coverslips covered with cells were incubated for $35 \mathrm{~min}$ at $37^{\circ} \mathrm{C}$ with $12 \mu \mathrm{mol} / \mathrm{l}$ of the fluorescent intracellular dye fura- 2 AM (Molecular Probes, Eugene, Ore., USA) plus $12 \mu \mathrm{l} / \mathrm{ml}$ of a $20 \%$ (w/v) stock Pluronic F-127 solution (Molecular Probes) in a shaking water bath. Following incubation, the cells were washed three times, a piece of the coverslip cut off with a diamond knife, transferred to a closed perfusion chamber of approximately $0.3 \mathrm{ml}$ volume and perfused at a flow rate of $1 \mathrm{ml} / \mathrm{min}$ by a peristaltic pump (Minipuls, Gilson, Middleton, Wis., USA). All experiments were performed at room temperature $\left(20-22^{\circ} \mathrm{C}\right)$.

The solution used for loading, washing and perfusion consisted of the following (in mmol/l): $145 \mathrm{NaCl}, 5 \mathrm{KCl}, 1 \mathrm{MgCl}_{2}$, $10 \mathrm{H}$-HEPES, $1 \mathrm{CaCl}_{2}, 1 \mathrm{D}$-glucose, $\mathrm{pH}$ adjusted to $\mathrm{pH} 7.35$ with $\mathrm{NaOH}$ at room temperature. In the experiments performed in the absence of glucose, this sugar was replaced with equimolar amounts of sucrose, glyceraldehyde or leucine. In experiments performed in the absence of $\mathrm{Ca}^{2+}$, a perfusion solution was used containing no added $\mathrm{CaCl}_{2}$ and $1.0 \mathrm{mmol} / \mathrm{l}$ EGTA. In experiments performed in $\mathrm{Na}^{+}$-free solution, $\mathrm{Na}^{+}$ was replaced by equimolar substitution of N-methyl-D-glucamine $\left(\mathrm{NMDG}^{+}\right)$.
M easurements of $\left[\mathrm{Ca}^{2+}\right]_{\mathrm{i}}$. Microfluorometric experiments were conducted using a Nikon Diaphot inverted microscope (Nikon Corporation, Tokyo, Japan) equipped with $\times 40$ Fluor objective. Fura-2 loaded cells were irradiated alternately with light at 340 and $380 \mathrm{~nm}$ using a filter wheel. The emitted light was passed through a $505 \pm 10 \mathrm{~nm}$ bandpass filter, detected by a photomultiplier and the resultant signal recorded on a 4-channel MacLab (ADInstruments Pty Ltd., Sydney, Australia). Fura-2 ratios (R) were calculated as 340/ 380 ratio and converted into $\left[\mathrm{Ca}^{2+}\right]_{\mathrm{i}}$ according to the equation derived by Grynkiewicz et al. [26]. The dissociation constant $\left(\mathrm{K}_{\mathrm{d}}\right)$ for Fura-2 at room temperature was taken to be $135 \mathrm{nmol} / \mathrm{l}$ [26]. Calibrations of the fura-2 signal were performed at the end of each study day. For calibration, the cells were exposed to a $150 \mathrm{mmol} / \mathrm{l} \mathrm{KCl}$ solution plus $2 \mu \mathrm{mol} / 1$ ionomycin ( $\mathrm{pH}$ 8.0) [27], containing either $10 \mathrm{mmol} / 1 \mathrm{EGTA}\left(\mathrm{R}_{\min }\right)$ or $10 \mathrm{mmol} / 1 \mathrm{CaCl}_{2}\left(\mathrm{R}_{\max }\right)$. The resting $\left[\mathrm{Ca}^{2+}\right]_{\mathrm{i}}$ measured in this study $(30 \mathrm{nmol} / \mathrm{l})$ is at the lower end of the reported range (see $[28,29])$. This may be because of the present experiments being carried out at room temperature.

M easurements of nitric oxide. Nitric oxide production from NIT-1 cells was assayed by measuring the production of nitrate and nitrite with the Griess reagent [30-32]. NIT-1 cells grown in $35 \mathrm{~mm}$ tissue culture Petri dishes were washed in perfusion solution before being incubated for $10 \mathrm{~min}$ at room temperature in the presence of either perfusion solution alone (as a control), or perfusion solution supplemented with one of the following: $20 \mathrm{mmol} / \mathrm{l} \mathrm{L}$-arginine, $20 \mathrm{mmol} / \mathrm{l}$ nitro-arginine, $20 \mathrm{mmol} / \mathrm{l}$ homoarginine or $100 \mu \mathrm{mol} / \mathrm{l} \mathrm{sin}-1$. Immediately following the stimulation, the samples were collected and stored at $-20^{\circ} \mathrm{C}$ until assayed. The cells were trypsinised off the dish and total cell numbers were counted with the use of a haemocytometer. The Griess reagent was added to the samples before being transferred to 96 multiwell plates and the absorbances read at $540 \mathrm{~nm}$ (Titertek Multiscan, Pathtech, Victoria, Australia). Measurements for the determination of nitrate required the reduction of this compound to nitrite by the addition of $0.6 \mathrm{mmol} / \mathrm{l} \mathrm{NADPH}$ and 5 units $/ \mathrm{ml}$ nitrate reductase before the addition of the Griess reagent. Results were read from standard curves for reduced $\mathrm{NaNO}_{3}$ and $\mathrm{NaNO}_{2}$ (4 to $1000 \mathrm{nmol} / \mathrm{l}$ ). Nitric oxide production was expressed as the concentration of nitrite plus nitrate $\left(\mathrm{NO}_{2}+\mathrm{NO}_{3}\right)$ and expressed as nmol $\cdot 10^{6}$ cells ${ }^{-1}$. $10 \mathrm{~min}^{-1}$.

M easurements of insulin release. NIT-1 cells grown in 35$\mathrm{mm}$ Petri dishes were washed in perfusion solution and then exposed for $10 \mathrm{~min}$ at room temperature to either perfusion solution alone (as a control), or to perfusion solution supplemented with one of the following: $20 \mathrm{mmol} / \mathrm{l}$ L-arginine, $20 \mathrm{mmol} / \mathrm{l}$ nitro-arginine, $20 \mathrm{mmol} / \mathrm{l}$ homoarginine, or $100 \mu \mathrm{mol} / \mathrm{l}$ sin-1. Following the stimulation, samples were collected and stored at $-20^{\circ} \mathrm{C}$ until assayed. The cells were trypsinised off the dish and total cell numbers were counted with the use of a haemocytometer. The levels of insulin secretion were measured by radioimmunoassay (RIA) using a rat standard (Novo Laboratories, Bagsvaerd, Denmark). Insulin release was expressed as $\mathrm{ng} \cdot 10^{6} \mathrm{cells}^{-1}$. $10 \mathrm{~min}^{-1}$.

Statistical analysis. Results are expressed as mean \pm SEM (number of observations). Statistical significance was assessed by using the Student's unpaired t-test, or analysis of variance (ANOVA) when variances were equal; and the Mann-Whitney non-parametric test when variances were unequal. 
Results

$\left[\mathrm{Ca}^{2+}\right]_{i}$ measurements

Response to insulin secretagogues. NIT-1 cells were exposed to glucose, glyceraldehyde and leucine, agents which are metabolised to form ATP, thereby increasing the cytosolic ATP/ADP ratio and closing $\mathrm{K}^{+}{ }_{\text {ATP }}$ channels $[17,33-38]$. The resting $\left[\mathrm{Ca}^{2+}\right]_{\mathrm{i}}$ in NIT- 1 cells was $30 \pm 1 \mathrm{nmol} / \mathrm{l}(\mathrm{n}=199)$. Exposure of NIT-1 cells to $20 \mathrm{mmol} / \mathrm{l}$ glucose elicited an increase in $\left[\mathrm{Ca}^{2+}\right]_{i}$ of $21 \pm 3 \mathrm{nmol} / 1(\mathrm{n}=6, \mathrm{p}<0.01)($ Fig. $1 \mathrm{~A})$ above resting levels. NIT-1 cells also responded to $20 \mathrm{mmol} / \mathrm{l}$ glyceraldehyde and $20 \mathrm{mmol} / 1$ leucine with increases in $\left[\mathrm{Ca}^{2+}\right]_{i}$ of $76 \pm 21 \mathrm{nmol} / 1 \quad(n=7$, $\mathrm{p}<0.02)$ (Fig. 1B) and $88 \pm 8 \quad \mathrm{nmol} / \mathrm{l} \quad(\mathrm{n}=13$, $p<0.01$ )(Fig. 1C), respectively. Membrane depolarisation following exposure to $20 \mathrm{mmol} / \mathrm{K} \mathrm{KCl}[10,11$, $34]$ produced an increase in $\left[\mathrm{Ca}^{2+}\right]_{\mathrm{i}}$ of $96 \pm 13 \mathrm{nmol} / 1$ $(n=7, p<0.01)$ (Fig. 1D) showing that depolarisation of the membrane potential leads to opening of voltage-activated $\mathrm{Ca}^{2+}$ channels in NIT-1 cells. These results demonstrate that the NIT-1 cell possesses the complete mechanism to translate stimulation by known secretagogues to an increase in $\left[\mathrm{Ca}^{2+}\right]_{\mathrm{i}}$.

Characterisation of arginine-induced beta-cell stimulation. Exposure of the NIT-1 cells to a 5-min pulse of arginine $(20 \mathrm{mmol} / \mathrm{l})$ caused an increase in $\left[\mathrm{Ca}^{2+}\right]_{\mathrm{i}}$ of $72 \pm 4 \mathrm{nmol} / \mathrm{l}(\mathrm{n}=76, \mathrm{p}<0.01)$ above resting levels. The increase in $\left[\mathrm{Ca}^{2+}\right]_{\mathrm{i}}$ occurred within $60 \mathrm{~s}$ of exposure reaching a peak within $152 \pm 31 \mathrm{~s} \quad(\mathrm{n}=10)$ (Fig. 2A). The magnitude of the increase in $\left[\mathrm{Ca}^{2+}\right]_{\mathrm{i}}$ in response to a second stimulus to $20 \mathrm{mmol} / \mathrm{l}$ arginine $(57 \pm 6 \mathrm{nmol} / \mathrm{l}, \mathrm{n}=14)$ was not significantly different from that observed in the first exposure $(p=0.474, n=14)$ (Fig. 2A), indicating that NIT-1 cells were not desensitized following repeated stimulation with arginine.

The increase in $\left[\mathrm{Ca}^{2+}\right]_{\mathrm{i}}$ in response to $20 \mathrm{mmol} / \mathrm{l}$ arginine was not dependent on extracellular $\mathrm{Na}^{+}$. When the $\mathrm{Na}^{+}$in the perfusion solution was replaced by $\mathrm{NMDG}^{+}$, exposure to $20 \mathrm{mmol} / \mathrm{l}$ arginine caused an increase in $\left[\mathrm{Ca}^{2+}\right]_{i}$ of $62 \pm 8 \mathrm{nmol} / 1 \quad(\mathrm{n}=5$, $p=0.150$ compared to arginine in the presence of $\mathrm{Na}^{+}$) (Fig. 2B), consistent with previous reports that arginine transport across the cell membrane occurs by a $\mathrm{Na}^{+}$-independent mechanism [39]. The removal of extracellular $\mathrm{Na}^{+}$caused a slight increase in $\left[\mathrm{Ca}^{2+}\right]_{\mathrm{i}}$ of $20 \pm 4 \mathrm{nmol} / \mathrm{l}(\mathrm{p}<0.001, \mathrm{n}=11)$ likely due to the inhibition of $\mathrm{Na}^{+} / \mathrm{Ca}^{2+}$ exchange which is present in these cells [40-42].

It is well established that arginine-induced insulin secretion from beta cells is nutrient dependent [18, $24,43,44]$. The arginine-induced increase in $\left[\mathrm{Ca}^{2+}\right]_{\mathrm{i}}$ in NIT-1 cells was also found to be nutrient dependent since removal of glucose from the extracellular solution inhibited the response to $20 \mathrm{mmol} / \mathrm{l}$ arginine
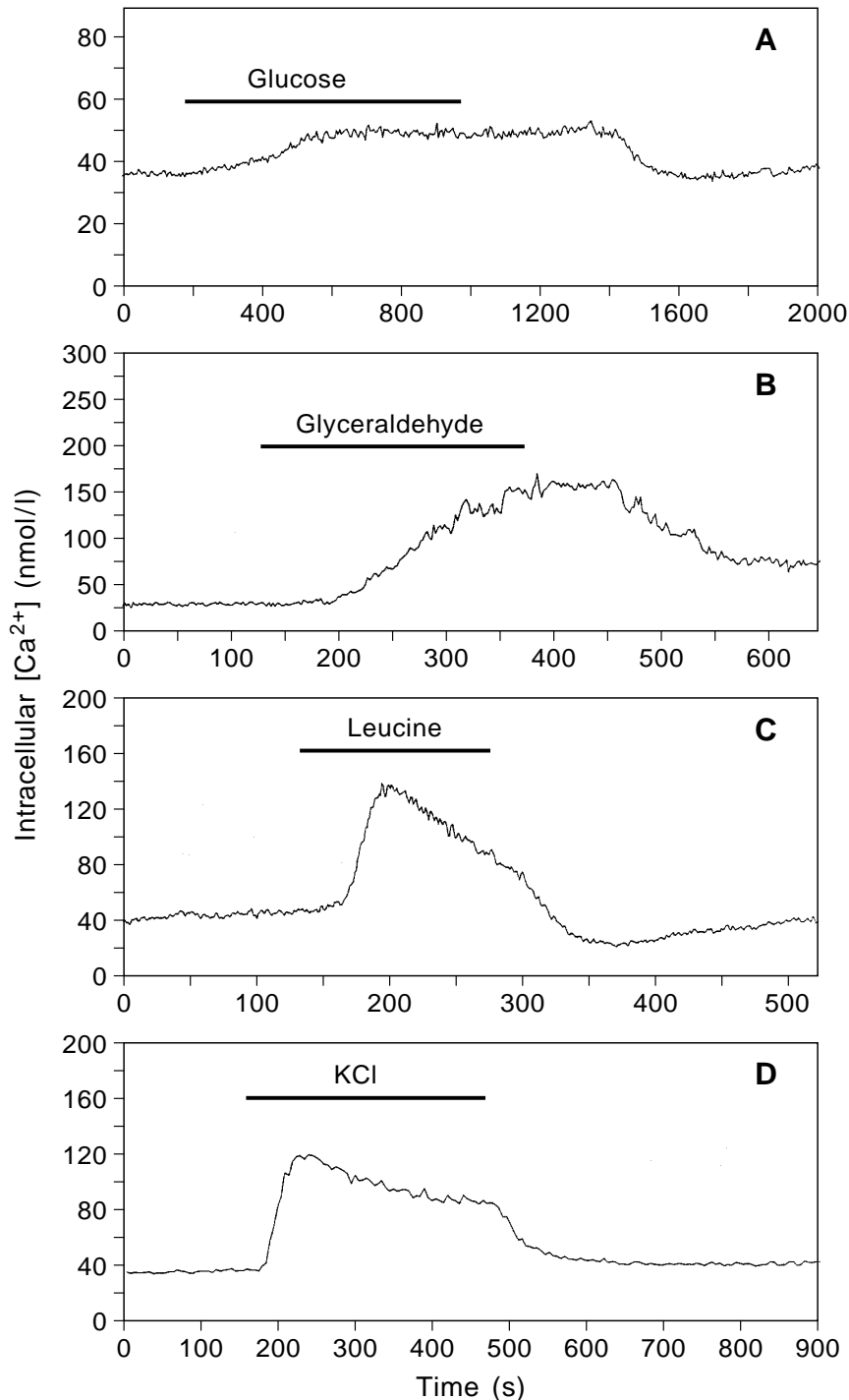

Fig. 1A -D. The effects of glucose (A), glyceraldehyde (B), leucine (C) and $\mathrm{KCl}$ (D) exposure on NIT-1 cells. The increase in glucose concentration (1 to $20 \mathrm{mmol} / \mathrm{l})$ and the addition of glyceraldehyde $(20 \mathrm{mmol} / \mathrm{l})$, leucine $(20 \mathrm{mmol} / \mathrm{l})$ and $\mathrm{KCl}$ $(20 \mathrm{mmol} / \mathrm{l})$ to the perifusion solution are indicated by the black bars

by $82 \pm 5 \%(n=10)$ compared to control $(p<0.001$, $\mathrm{n}=10$ ) (Fig. 2C). When glucose was replaced by other nutrients, the arginine-induced increase in $\left[\mathrm{Ca}^{2+}\right]_{\mathrm{i}}$ was also observed. Exposure of the cells to $20 \mathrm{mmol} / \mathrm{l}$ arginine in the perfusion solutions in which the glucose was replaced by either $1 \mathrm{mmol} / \mathrm{l}$ glyceraldehyde or $1 \mathrm{mmol} / \mathrm{l}$ leucine, caused increases in $\left[\mathrm{Ca}^{2+}\right]_{\mathrm{i}}$ of $66 \pm 4 \mathrm{nmol} / \mathrm{l}(\mathrm{n}=3)$, and $55 \pm 14 \mathrm{nmol} / \mathrm{l}$ $(\mathrm{n}=3)$, respectively, not significantly different from the responses observed in the presence of glucose. In contrast, the response to direct membrane depolarisation by $20 \mathrm{mmol} / \mathrm{l} \mathrm{KCl}$ was not significantly inhibited by the removal of glucose compared to controls $(15 \pm 8 \%$ inhibition, $n=3)$. Diazoxide, a specific activator of $\mathrm{K}^{+}{ }_{\text {ATP }}$ channels $[35,45]$, is able to counter 

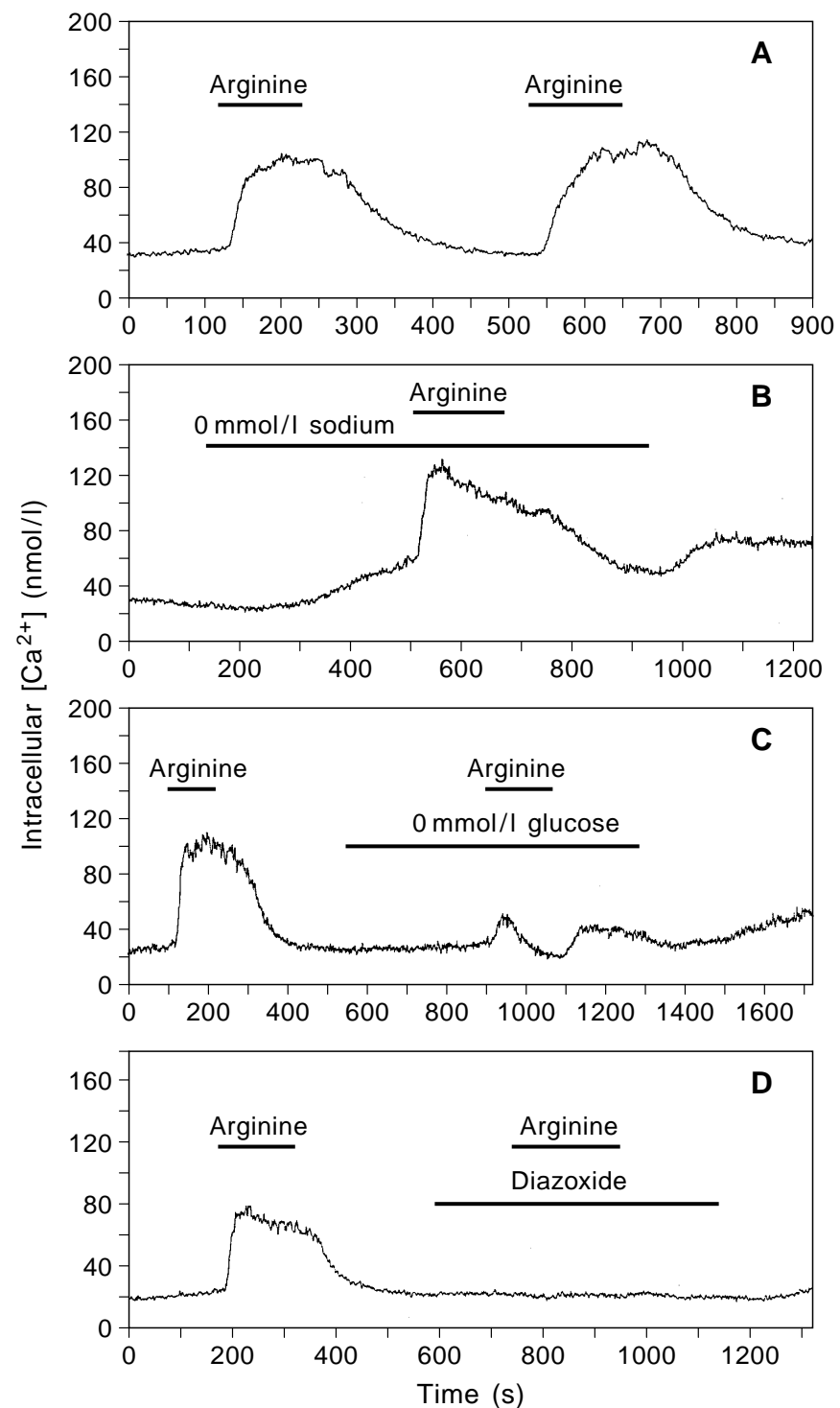

Fig. 2A - D. The effect of iterative stimulation $(\mathbf{A})$, the removal of extracellular sodium (B), the removal of extracellular glucose (C) and the exposure of diazoxide (D) on arginine-induced increase in $\left[\mathrm{Ca}^{2+}\right]_{\mathrm{i}}$ in NIT-1 cells. The addition of arginine $(20 \mathrm{mmol} / \mathrm{l})$ and diazoxide $(100 \mu \mathrm{mol} / \mathrm{l})$; as well as the decrease in glucose concentration (1 to $0 \mathrm{mmol} / \mathrm{l})$ and the removal of sodium from the perifusion solution are indicated by the black bars

membrane depolarisation in beta cells [9, 45-48]. Exposure of NIT-1 cells to diazoxide $(100 \mu \mathrm{mol} / \mathrm{l}) \mathrm{did}$ not change the $\left[\mathrm{Ca}^{2+}\right]_{\mathrm{i}}$ during a 5-min exposure $(2 \pm 1 \mathrm{nmol} / \mathrm{l}, \mathrm{n}=9)$, but inhibited the response to $20 \mathrm{mmol} / \mathrm{l}$ arginine by $97.5 \pm 1.4 \%(\mathrm{p}<0.001, \mathrm{n}=10)$ (Fig. 2D), suggesting that arginine-induced depolarisation of the membrane potential can be prevented by activation of the $\mathrm{K}^{+}{ }_{\text {ATP }}$ channels.

Experiments were conducted to determine if the arginine-induced increase in $\left[\mathrm{Ca}^{2+}\right]_{i}$ was due to $\mathrm{Ca}^{2+}$ flux from the extracellular solution. Removal of $\mathrm{Ca}^{2+}$ from the extracellular solution caused a decrease in $\left[\mathrm{Ca}^{2+}\right]_{\mathrm{i}}$ of $25 \pm 4 \mathrm{nmol} / \mathrm{l}$ from resting levels $(p<0.01, n=11)$. In addition, the removal of extracellular $\mathrm{Ca}^{2+}$ completely inhibited the response to $20 \mathrm{mmol} / \mathrm{l}$ arginine $(\mathrm{p}<0.001, \mathrm{n}=11)$ (Fig. 3A). Exposure of NIT-1 cells to ATP, which binds to cell surface receptors and causes release of $\mathrm{Ca}^{2+}$ from intracellular stores in beta cells $[29,49]$, caused an increase in $\left[\mathrm{Ca}^{2+}\right]_{\mathrm{i}}$ of $110 \pm 41 \mathrm{nmol} / \mathrm{l}(100 \mu \mathrm{mol} / \mathrm{l} \mathrm{ATP}, \mathrm{n}=3)$ and $50 \pm 8 \mathrm{nmol} / \mathrm{l}(10 \mu \mathrm{mol} / \mathrm{l} \mathrm{ATP}, \mathrm{n}=2)$, respectively, in the presence of $1 \mathrm{mmol} / 1$ extracellular $\mathrm{Ca}^{2+}$. In the absence of extracellular $\mathrm{Ca}^{2+}$, there was no inhibition of the response to either $100 \mu \mathrm{mol} / 1 \mathrm{ATP}$ or $10 \mu \mathrm{mol} / 1$ ATP $(17 \pm 2 \%, n=3$ and $0 \pm 16 \%, n=3$, respectively), indicating that the response to ATP was attributable solely to intracellular $\mathrm{Ca}^{2+}$ stores. These results show that the arginine-induced increase in $\left[\mathrm{Ca}^{2+}\right]_{i}$ is dependent upon $\mathrm{Ca}^{2+}$ influx from the extracellular solution and does not involve release from intracellular stores.

The addition of $20 \mu \mathrm{mol} / \mathrm{l}$ verapamil, a blocker of voltage-activated $\mathrm{Ca}^{2+}$ channels in beta cells [1,50$52]$, had no effect on resting $\left[\mathrm{Ca}^{2+}\right]_{\mathrm{i}}$ in NIT-1 cells $(n=9)$. It did, however, significantly inhibit the response to $20 \mathrm{mmol} / \mathrm{l}$ arginine by $86.0 \pm 4.6 \%$ $(p<0.001, n=9)$ (Fig. 3B). This demonstrates that the arginine-induced increase in $\left[\mathrm{Ca}^{2+}\right]_{i}$ in NIT-1 cells occurs due to the influx of $\mathrm{Ca}^{2+}$ from the extracellular solution via voltage-activated $\mathrm{Ca}^{2+}$ channels.

The effect of nitric oxide producing agents. The production of nitric oxide has been implicated as the mechanism involved in arginine-induced stimulation of beta cells [21], and has been shown to cause an increase in $\left[\mathrm{Ca}^{2+}\right]_{\mathrm{i}}$ in endothelial cells $[53,54]$. Experiments were performed to investigate the effects of increasing the intracellular nitric oxide concentration on $\left[\mathrm{Ca}^{2+}\right]_{\mathrm{i}}$ in the NIT- 1 cell.

Sin-1 was used for this purpose because of previous reports showing that it causes an increase in the cytosolic concentration of nitric oxide in beta cells [21]. Exposure of the NIT- 1 cells to $100 \mu \mathrm{mol} / \mathrm{l} \sin -1$ caused an increase in $\left[\mathrm{Ca}^{2+}\right]_{i}$ of $89 \pm 11 \mathrm{nmol} / 1$ $(\mathrm{n}=11)$ (Fig. 4A). The magnitude of this increase was not significantly different from that caused by $20 \mathrm{mmol} / \mathrm{l} \mathrm{L}$-arginine $(\mathrm{n}=11)$. Removal of extracellular glucose inhibited the response to $100 \mu \mathrm{mol} / 1 \mathrm{sin}-1$ by $54.8 \pm 15.4 \%(p=0.024, n=3)$, an effect similar to that of the removal of glucose on the arginine-induced increase in $\left[\mathrm{Ca}^{2+}\right]_{\mathrm{i}}$.

NIT-1 stimulation by arginine analogues. In order to further investigate the role of nitric oxide production in the arginine-induced increase in $\left[\mathrm{Ca}^{2+}\right]_{i}$, we repeated the experiments with the arginine analogues nit-arginine and me-arginine which are not substrates for nitric oxide synthase and therefore do not generate nitric oxide in beta cells [22, 55-57]. Exposure of the NIT-1 cells to $20 \mathrm{mmol} / \mathrm{l}$ nit-arg and $20 \mathrm{mmol} / \mathrm{l}$ 

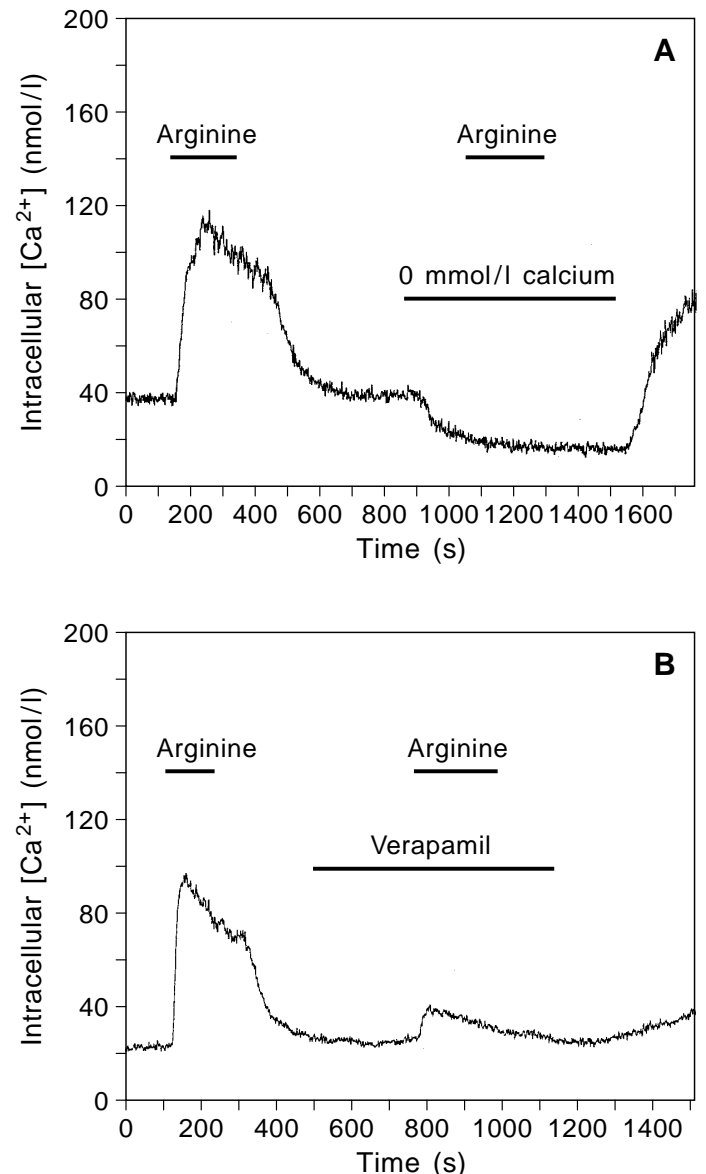

Fig. 3A , B. The effect of the removal of extracellular $\mathrm{Ca}^{2+}(\mathbf{A})$ and of the addition of the $\mathrm{Ca}^{2+}$ channel blocker verapamil (B) on the arginine-induced increase in $\left[\mathrm{Ca}^{2+}\right]_{\mathrm{i}}$ by NIT- 1 cells. The removal of calcium; and the addition of arginine $(20 \mathrm{mmol} / \mathrm{l})$ and verapamil $(20 \mu \mathrm{mol} / \mathrm{l})$ to the perifusion solution are indicated by the black bars

me-arg caused increases in $\left[\mathrm{Ca}^{2+}\right]_{\mathrm{i}}$ of $83 \pm 7 \mathrm{nmol} / \mathrm{l}$ $(n=13)$ and $74 \pm 10 \mathrm{nmol} / \mathrm{l},(n=5)$ (Fig. 5). At all concentrations examined (0.01-20 mmol/l) (Fig.5), the responses to nit-arginine and me-arginine were not significantly different from those to L-arginine. Removal of extracellular $\mathrm{Ca}^{2+}$ inhibited the response to nit-arginine by $83 \pm 3 \%(n=3)$, just as it did for Larginine.

The arginine-analogue homoarginine [23, 24, 58], and the arginine enantiomer D-arginine [57, 59], are non-metabolisable and are not substrates for nitric oxide synthase for the production of nitric oxide in the beta cell. Exposure of the NIT-1 cells to $20 \mathrm{mmol} / \mathrm{l}$ homoarginine and $20 \mathrm{mmol} / \mathrm{l} \mathrm{D}$-arginine caused increases in $\left[\mathrm{Ca}^{2+}\right]_{\mathrm{i}}$ of $39 \pm 7 \mathrm{nmol} / \mathrm{l}(\mathrm{n}=7)$ and $26 \pm 3 \mathrm{nmol} / \mathrm{l}(\mathrm{n}=9)$ (Fig. 5). These responses were not significantly different from each other at any concentration $(0.01-20 \mathrm{mmol} / \mathrm{l})$, but were significantly less than those to $\mathrm{L}$-arginine at concentrations above $10 \mathrm{mmol} / \mathrm{l}(\mathrm{p}=0.030, \mathrm{n}=7)$ and below $1 \mathrm{mmol} / \mathrm{l}(\mathrm{p}=0.004, \mathrm{n}=3)$.

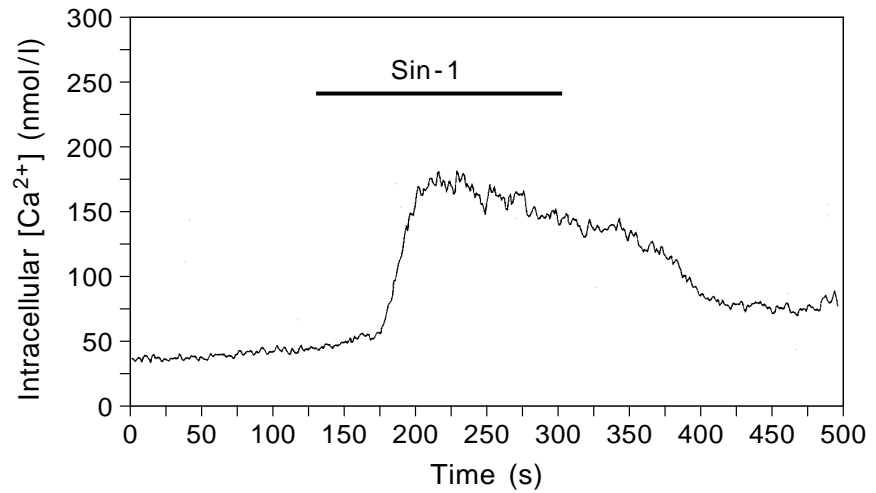

Fig. 4. The effect of the nitric oxide producer $\sin -1$ on $\left[\mathrm{Ca}^{2+}\right]_{i}$ in NIT-1 cells. The addition of $\sin -1(100 \mu \mathrm{mol} / \mathrm{l})$ to the perifusion solution is indicated by the black bar

Since these results suggested that the production of nitric oxide was not involved in the arginine-induced increase in $\left[\mathrm{Ca}^{2+}\right]_{i}$, we tested this hypothesis by using a different agent, sodium nitroprusside (SNP), to elevate nitric oxide levels. Exposure of the cells to $1 \mathrm{mmol} / 1 \mathrm{SNP}$ had no effect on the levels of $\left[\mathrm{Ca}^{2+}\right]_{\mathrm{i}}$ (change in $\left[\mathrm{Ca}^{2+}\right]_{\mathrm{i}}-1 \pm 1 \mathrm{nmol} / \mathrm{l}, \mathrm{n}=5$ ). This result is further evidence that nitric oxide is not involved in the arginine-induced increase in $\left[\mathrm{Ca}^{2+}\right]_{i}$.

\section{Nitric oxide measurements}

Exposure of NIT-1 cells for $10 \mathrm{~min}$ to $20 \mathrm{mmol} / \mathrm{l}$ $\mathrm{L}$-arginine and $100 \mu \mathrm{mol} / \mathrm{l}$ sin- 1 caused the production of $29.8 \pm 4.8$ and $36.7 \pm 3.0 \mathrm{nmol} / \mathrm{l}$ nitric oxide $\left(\mathrm{NO}_{2}+\mathrm{NO}_{3}\right) \cdot 10^{6}$ cells $^{-1} \cdot 10 \mathrm{~min}^{-1}(\mathrm{n}=3$ preparations each in quintuplicate) (Fig. 6A). Exposure of the cells to the perfusion solution (control), $20 \mathrm{mmol} / \mathrm{l}$ nit-arg and $20 \mathrm{mmol} / \mathrm{l}$ homoarginine failed to stimulate the production of nitric oxide above detectable levels $\left(4 \mathrm{nmol} / 1 \cdot 10^{6}\right.$ cells $\left.^{-1} \cdot 10 \mathrm{~min}^{-1}\right)(\mathrm{n}=3)$.

\section{Insulin secretion measurements}

Insulin release measurements are summarised in Figure $6 \mathrm{~B}$ ( $\mathrm{n}=3$ for all experiments). The NIT-1 cells released $2.7 \pm 0.4 \mathrm{ng}$ insulin $\cdot 10^{6} \cdot$ cells in $10 \mathrm{~min}$ during incubation in perfusion solution alone (control). Exposure to $100 \mu \mathrm{mol} / \mathrm{l} \sin -1,20 \mathrm{mmol} / \mathrm{l} \mathrm{L}$-arginine, $20 \mathrm{mmol} / \mathrm{l}$ nitro-arginine and $20 \mathrm{mmol} / \mathrm{l}$ homoarginine caused the release of insulin at $4.7 \pm 0.5$, $6.0 \pm 1.3, \quad 9.9 \pm 1.3$ and $6.9 \pm 1.9 \mathrm{ng} \cdot 10^{6} \cdot$ cells $^{-1}$. $10 \mathrm{~min}^{-1}$, respectively. These agents all released insulin in amounts significantly greater than the amount released by the control $(p=0.017,0.028,0.003$, and 0.016 ), but did not differ significantly from one another.

\section{Discussion}

Arginine is a well-known secretagogue for the stimulation of insulin release from the pancreatic beta 


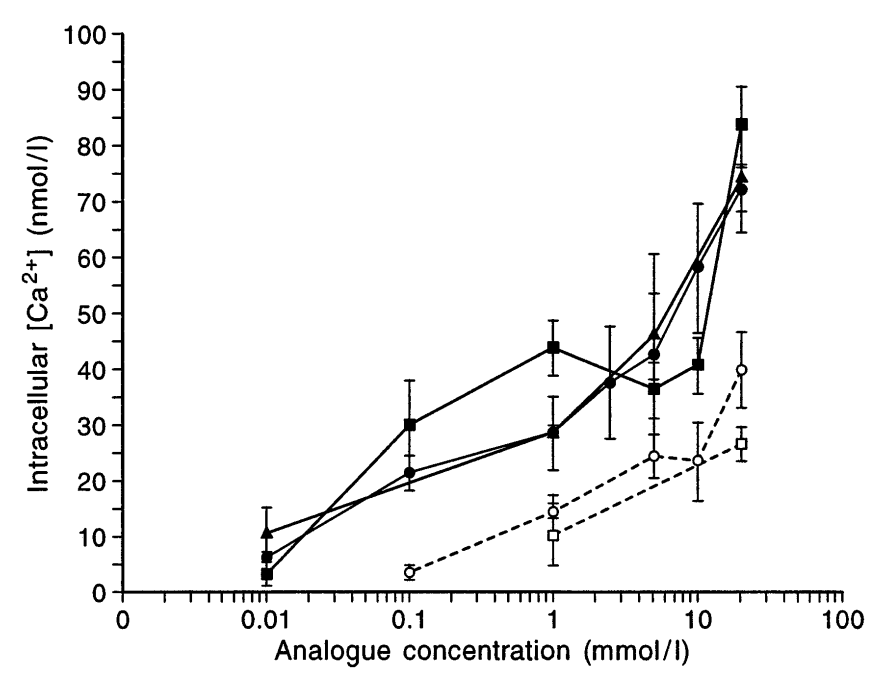

Fig. 5. Dose response curves $(0.01-20 \mathrm{mmol} / \mathrm{l})$ for the increases in $\left[\mathrm{Ca}^{2+}\right]_{\mathrm{i}}$ in response to $\mathrm{L}$-arginine $(\mathbf{O})$, and the arginine analogues nit-arg $(\square)$, met-arg $(\boldsymbol{\Delta})$, homoarginine $(\bigcirc)$ and D-arginine $(\square)$

cell. The mechanism by which arginine-induced stimulation occurs is, however, not well characterised. Our data are consistent with a mechanism in which arginine enters NIT-1 cells via a $\mathrm{Na}^{+}$-independent transport system, as previously described [39, 60]. Interestingly, the concentration-response curve for arginine (Fig.5) suggests the presence of two distinct transporter systems for arginine and its analogues, one with an affinity for arginine of approximately $100 \mu \mathrm{mol} / 1$, the other with an affinity in the millimolar range. These correspond with the known affinities of the amino acid transporters MCAT-1 and MCAT-2 a which are present in islet cells [60]. Since the plasma level of arginine in fasted animals is approximately $100 \mu \mathrm{mol} / \mathrm{l}$ [61], the higher affinity component is likely to be physiologically relevant.

The arginine-induced increase in $\left[\mathrm{Ca}^{2+}\right]_{\mathrm{i}}$ is dependent upon the influx of extracellular $\mathrm{Ca}^{2+}$ and occurs via verapamil-sensitive and voltage-activated $\mathrm{Ca}^{2+}$ channels. This arginine-induced increase in $\left[\mathrm{Ca}^{2+}\right]_{\mathrm{i}} \mathrm{re}-$ quires the presence of a nutrient and is inhibited by the activation of $\mathrm{K}^{+}{ }_{\text {ATP }}$ channels with diazoxide. These observations suggest that the $\mathrm{K}^{+}{ }_{\text {ATP }}$ channels, when fully open, act to prevent membrane depolarisation caused by arginine. The presence of a nutrient, such as glucose, produces sufficient closure of $\mathrm{K}^{+}{ }_{\text {ATP }}$ channels to allow arginine-induced membrane depolarisation and activation of the voltage-activated $\mathrm{Ca}^{2+}$ channels. Our observations are consistent with previous reports in which arginine-induced stimulation of insulin was abolished by the complete removal of ATP from permeabilised islets [62], patch-clamp experiments that demonstrated that arginine alone did not cause the closure of $\mathrm{K}^{+}{ }_{\text {ATP }}$ channels [35] and radioisotope studies which demonstrated that arginine exposure did not cause a reduction in ${ }^{86} \mathrm{Rb}^{+}$efflux $[18,63]$.
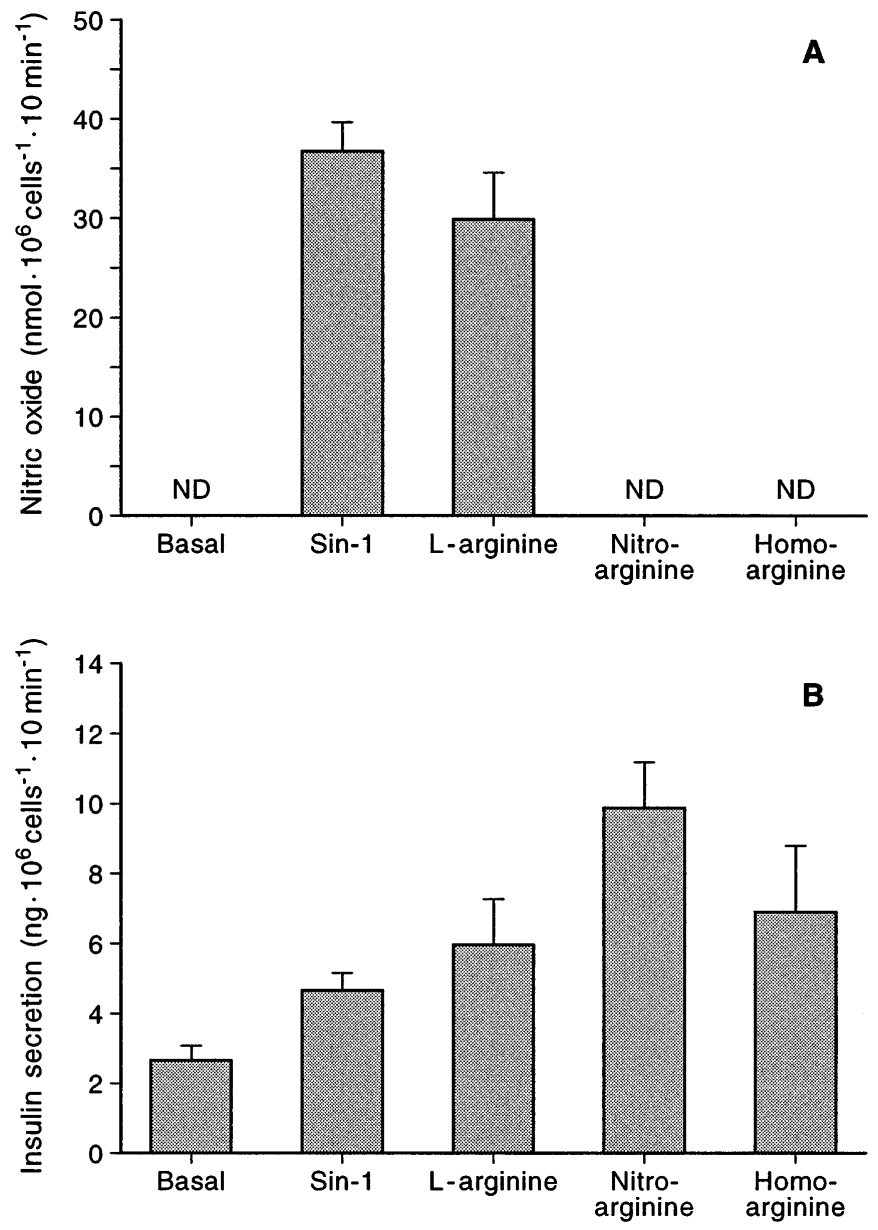

Fig. 6. Nitric oxide production (A) and insulin secretion (B) from NIT-1 cells in response to sin-1 $(100 \mu \mathrm{mol} / \mathrm{l}), \mathrm{L}$-arginine $(20 \mathrm{mmol} / \mathrm{l})$, nitro-arginine $(20 \mathrm{mmol} / \mathrm{l})$ and homoarginine $(20 \mathrm{mmol} / \mathrm{l})(\mathrm{n}=3$ preparations measured in quintuplicate in all experiments)

There are considerable inconsistencies in the literature about whether arginine-induced insulin secretion is due to nitric oxide production. A number of studies have suggested that arginine-induced insulin release was caused by an increase in the cytosolic nitric oxide concentration. For example, nitarginine and me-arginine inhibited insulin secretion in rat beta cells, HIT-T15 insulinoma cells [21, 57] and from perfused rat pancreas [22]. In contrast, other studies have shown that nit-arginine and mearginine [22, 64], as well as homoarginine and Darginine $[24,57,65]$ all caused insulin release from rat islets. Studies using electropermeablised rat islets demonstrated that the addition of either nitarginine or me-arginine with L-arginine inhibited arginine-derived nitric oxide production without affecting insulin release [56]. In addition, nit-arginine alone did not increase insulin release from isolated mouse islets, but when combined with L-arginine markedly increased $\mathrm{D}$-arginine-induced insulin release [66]. 
The present results demonstrate by fluorimetric measurements that the arginine analogues, nit-arginine and met-arginine, which do not produce nitric oxide, cause increases in $\left[\mathrm{Ca}^{2+}\right]_{\mathrm{i}}$ in beta cells similar to those caused by L-arginine. We also show that the arginine analogues which are completely non-metabolisable, homoarginine and $\mathrm{D}$-arginine, cause an increase in $\left[\mathrm{Ca}^{2+}\right]_{\mathrm{i}}$ although to a smaller extent than those caused by L-arginine. From the present data it is not possible to state whether the lesser effects on $\left[\mathrm{Ca}^{2+}\right]_{\mathrm{i}}$ of these non-metabolisable analogues are attributable entirely to them having lower affinities for the arginine transport system, or to metabolism of Larginine, nit-arginine and met-arginine playing some role in producing the $\left[\mathrm{Ca}^{2+}\right]_{i}$ response. The production of ATP from the metabolism of L-arginine alone is not likely to be this hypothetical metabolism-dependent mechanism because $\mathrm{L}$-arginine stimulation does not lead to the closure of $\mathrm{K}^{+}{ }_{\text {ATP }}$ channels in patch-clamp studies [35], nor does it increase $\left[\mathrm{Ca}^{2+}\right]_{\mathrm{i}}$ in the absence of glucose in the present study. Alternatives to the production of ATP by the metabolism of arginine include the formation of polyamines [20, 67].

In addition, because the nitric oxide producer nitroprusside did not cause an increase in $\left[\mathrm{Ca}^{2+}\right]_{\mathrm{i}}$, the increased $\left[\mathrm{Ca}^{2+}\right]_{\mathrm{i}}$ observed in the presence of $\sin -1$ was presumably attributable to the transport of this zwitterionic compound into the cell, rather than to nitric oxide release. These findings indicate that nitric oxide production is not the mechanism leading to the arginine-induced increase $\left[\mathrm{Ca}^{2+}\right]_{\mathrm{i}}$ in NIT- 1 cells, rather it is due to a process involving electrogenic transport of arginine and its analogues leading to depolarisation of the plasma membrane.

The fluorimetric data are supported by insulin release data which demonstrate that the agents which were able to cause an increase in $\left[\mathrm{Ca}^{2+}\right]_{\mathrm{i}}$ such as sin-1, L-arginine, nit-arg and homoarginine were also able to stimulate the release of insulin. The analogues of arginine caused similar amounts of insulin release suggesting that arginine-induced stimulation in beta cells has a threshold $[23,24]$ such that an increase in $\left[\mathrm{Ca}^{2+}\right]_{i}$, even to the extent caused by homoarginine, is sufficient in itself to cause insulin secretion. Beyond this threshold a further increase in $\left[\mathrm{Ca}^{2+}\right]_{i}$ does not further enhance insulin release.

In conclusion, these results suggest that in NIT-1 cells, L-arginine does not act via the nitric oxide pathway since nit-arg and met-arg which do not produce nitric oxide, caused increases in $\left[\mathrm{Ca}^{2+}\right]_{\mathrm{i}}$ and insulin release to the same extent as L-arginine. The data suggest that the arginine-induced increase in $\left[\mathrm{Ca}^{2+}\right]_{i}$ occurs as a result of membrane depolarisation caused by the cationic amino acid, although metabolism of the amino acid itself may also partially contribute to the response.
A cknowledgements. This work was partially supported by the National Health and Medical Research Council of Australia; the Australian Department of Employment, Education and Training, and a University of Sydney, University Postgraduate Research Award for A.J.W.

The expert technical assistance of S. Beynon and B. Tang is gratefully acknowledged.

\section{References}

1. Pralong WF, Bartley C, Wollheim CB (1990) Single islet $\beta$ cell stimulation by nutrients: relationship between pyridine nucleotides, cytosolic $\mathrm{Ca}^{2+}$ and secretion. EMBO J 9: 53-60

2. Prentki M, Matschinsky F (1987) $\mathrm{Ca}^{2+}$, cAMP, and phospholipid-derived messengers in coupling mechanisms of insulin secretion. Physiol Rev 67: 1185-1248

3. Hoenig M, Sharp GWG (1986) Glucose induces insulin release and a rise in cytosolic calcium concentration in a transplantable rat insulinoma. Endocrinology 119: 25022507

4. Wollheim CB, Sharp GWG (1981) Regulation of insulin release by calcium. Physiol Rev 61: 914-973

5. Dunne MJ, Petersen OH (1986) Intracellular ADP activates $\mathrm{K}^{+}$channels that are inhibited by ATP in an insulinsecreting cell line. FEBS Lett 208: 59-62

6. Cook DL, Hales CN (1984) Intracellular ATP directly blocks $\mathrm{K}^{+}$channels in pancreatic B-cells. Nature 311 : 271-273

7. Misler S, Barnett DW, Pressel DM, Gillis KD, Scharp DW, Falke LC (1992) Stimulus-secretion coupling in $\beta$-cells of transplantable human islets of Langerhans: evidence for a critical role for $\mathrm{Ca}^{2+}$ entry. Diabetes 41: 662-670

8. Smith PA, Ashcroft FM, Rorsman P (1990) Simultaneous recordings of glucose dependent electrical activity and ATP-regulated $\mathrm{K}^{+}$-current in isolated mouse pancreatic B-cells. FEBS Lett 261: 187-190

9. Valdeolmillos M, Nadal A, Contreras D, Soria B (1992) The relationship between glucose-induced $\mathrm{K}^{+}{ }_{\text {ATP }}$ channel closure and the rise in $\left[\mathrm{Ca}^{2+}\right]_{\mathrm{i}}$ in single mouse pancreatic B-cells. J Physiol (Lond) 455: 173-186

10. Smith PA, Ashcroft FM, Fewtrell CMS (993) Permeation and gating properties of the L-type calcium channel in mouse pancreatic B-cells. J Gen Physiol 101: 767-797

11. Gilon P, Henquin J-C (1992) Influence of membrane potential changes on cytoplasmic $\mathrm{Ca}^{2+}$ concentration in an electrically excitable cell, the insulin-secreting pancreatic B-cell. J Biol Chem 267: 20713-20720

12. Plasman PO, Hermann M, Herchuelz A, Lebrun P (1990) Sensitivity to $\mathrm{Cd}^{2+}$ but resistance to $\mathrm{Ni}^{2+}$ of $\mathrm{Ca}^{2+}$ inflow into rat pancreatic islets. Am J Physiol 258:E529-E533

13. Tuch BE, Osgerby KJ, Turtle JR (1990) The role of calcium in insulin release from the human fetal pancreas. Cell Calcium 11: 1-9

14. Ammon HPT, Glocker C, Waldner RG, Wahl MA (1989) Insulin release from pancreatic islets of fetal rats mediated by leucine b-BCH, tolbutamide, glibenclamide, arginine, potassium chloride, and theophylline does not require stimulation of $\mathrm{Ca}^{2+}$ net uptake. Cell Calcium 10: 441-450

15. Heinze E, Steinke J (1972) Insulin secretion during development: response of isolated pancreatic islets of fetal, newborn and adult rats to theophylline and arginine. Horm Metab Res 4: 234-236

16. Weinhaus AJ, Poronnik P, Cook DI, Tuch BE (1995) Insulin secretagogues, but not glucose, stimulate an increase in $\left[\mathrm{Ca}^{2+}\right]_{\mathrm{i}}$ in the fetal rat $\beta$-cell. Diabetes 44: 118-124 
17. Grapengiesser E, Gylfe E, Hellman B (1989) $\mathrm{Ca}^{2+}$ oscillations in pancreatic B-cells exposed to leucine and arginine. Acta Physiol Scand 136: 113-119

18. Charles S, Tamagawa T, Henquin J-C (1982) A single mechanism for the stimulation of insulin release and ${ }^{86} \mathrm{Rb}^{+}$efflux from rat islets by cationic amino acids. Biochem J 208: 301-308

19. Malaisse WJ, Blachier F, Mourtada A, Camara J, Albor A, Valverde I, Sener A (1989) Stimulus-secretion coupling of arginine-induced insulin release: metabolism of L-arginine and L-ornithine in tumoral islet cells. Mol Cell Endocrinol 67: 81-91

20. Malaisse WJ, Blachier F, Mourtada A, Camara J, Albor A, Valverde I, Sener A (1989) Stimulus-secretion coupling of arginine-induced insulin release. Metabolism of L-arginine and L-ornithine in pancreatic islets. Biochim Biophys Acta 1013: 133-143

21. Schmidt HHHW, Warner TD, Ishii K, Sheng H, Murad F (1992) Insulin secretion from pancreatic B cells caused by L-arginine-derived nitrogen oxides. Science 255: 721-723

22. Jansson L, Sandler S (1991) The nitric oxide synthase II inhibitor NG-nitro-L-arginine stimulates pancreatic islet insulin release in vitro, but not in the perfused pancreas. Endocrinology 128: 3081-3085

23. Sener A, Blachier F, Rasschaert J, Mourtada A, MalaisseLagae F, Malaisse WJ (1989) Stimulus-secretion coupling of arginine-induced insulin release: comparison with lysine-induced insulin secretion. Endocrinology 124: 25582567

24. Blachier F, Mourtada A, Sener A, Malaisse WJ (1989) Stimulus-secretion coupling of arginine-induced insulin release. Uptake of metabolized and nonmetabolized cationic amino acids by pancreatic islets. Endocrinology 124: 134-141

25. Hamaguchi K, Gaskins HR, Leiter EH (1991) NIT-1, a pancreatic $\beta$-cell line established from a transgenic NOD/ Lt mouse. Diabetes 40: 842-849

26. Grynkiewicz G, Poenie M, Tsien RY (1985) A new generation of $\mathrm{Ca}^{2+}$ indicators with greatly improved fluorescence properties. J Biol Chem 260: 3440-3455

27. Williams DA, Fay FS (1990) Intracellular calibration of the fluorescent calcium indicator Fura-2. Cell Calcium 11: 7583

28. Okamoto Y, Ishida H, Taminato Tet al. (1992) Role of cytosolic $\mathrm{Ca}^{2+}$ in impaired sensitivity to glucose of rat pancreatic islets exposed to high glucose in vitro. Diabetes 41: $1555-1561$

29. Theler J-M, Mollard P, Guerineau N, Vacher P, Pralong WF, Schlegel W, Wollheim CB (1992) Video imaging of cytosolic $\mathrm{Ca}^{2+}$ in pancreatic B-cells stimulated by glucose, carbachol, and ATP. J Biol Chem 267: 18110-18117

30. Wu G, Brosnan JT (1992) Macrophages can convert citrulline into arginine. Biochem $\mathrm{J}$ 281: 45-48

31. Saltzman BE (1954) Colorimetric microdetermination of nitrogen dioxide in the atmosphere. Anal Chem 26: 19491955

32. Green LC, RuizdeLuzuriaga K, Wagner DA, Rand W, Istfan N, Young VR, Tannenbaum SR (1981) Nitrate biosynthesis in man. Proc Natl Acad Sci USA 78: 7764-7768

33. Tsuura Y, Ishida H, Okamoto Yet al. (1993) Glucose sensitivity of ATP-sensitive $\mathrm{K}^{+}$channels is impaired in B-cells of the GK Rat. Diabetes 42: 1446-1453

34. Eddlestone GT, Ribalet B, Ciani S (1989) Comparative study of $\mathrm{K}^{+}$channel behavior in B cell lines with different secretory responses to glucose. J Membr Biol 109: 123-134

35. Misler S, Gee WM, Gillis KD, Scharp DW, Falke LC (1989) Metabolite-regulated ATP-sensitive $\mathrm{K}^{+}$channel in human pancreatic islet cells. Diabetes 38: 422-427
36. Henquin JC, Meissner HP (1981) Effects of amino acids on membrane potential and ${ }^{86} \mathrm{Rb}^{+}$fluxes in pancreatic B-cells. Am J Physiol 240:E245-E252

37. Misler S, Falke LC, Gillis K, McDaniel ML (1986) A metabolite-regulated potassium channel in rat pancreatic Bcells. Proc Natl Acad Sci USA 83: 7119-7123

38. Dean PM, Matthews EK, Sakamoto Y (1975) Pancreatic islet cells: effects of monosaccharides, glycolytic intermediates and metabolic inhibitors on membrane potential and electrical activity. J Physiol (Lond) 246: 459-478

39. White MF (1985) The transport of cationic amino acids across the plasma membrane of mammalian cells. Biochim Biophys Acta 822: 356-373

40. Herchuelz A, Plasman P-O (1991) Sodium-calcium exchange in the pancreatic B cell. Ann NY Acad Sci 639: 644-656

41. Plasman P-O, Herchuelz A (1992) Regulation of $\mathrm{Na}^{+} /$ $\mathrm{Ca}^{2+}$ exchange in the rat pancreatic $\mathrm{B}$ cell. Biochem $\mathrm{J}$ 285: $123-127$

42. Rorsman P, Ammala C, Berggren P-O, Bokvist K, Larsson O (1992) Cytoplasmic calcium transients due to single action potentials and voltage-clamp depolarizations in mouse pancreatic B-cells. EMBO J 11: 2877-2884

43. Sener A, Lebrun P, Blachier F, Malaisse WJ (1989) Stimulus-secretion coupling of arginine-induced insulin release. Biochem Pharmacol 38: 327-330

44. Blachier F, Leclercq-Meyer V, Marchand J, Woussen-Colle M-C, Mathias PCF, Sener A, Malaisse WJ (1989) Stimulus-secretion coupling of arginine-induced insulin release. Functional response of islets to L-arginine and L-ornithine. Biochim Biophys Acta 1013: 144-151

45. Dunne MJ, Yule DI, Gallacher DV, Petersen OH (1990) Comparative study of the effects of cromakalim (BRL $34915)$ and diazoxide on membrane potential, $\left[\mathrm{Ca}^{2+}\right]_{\mathrm{i}}$ and ATP-sensitive potassium currents in insulin-secreting cells. J Membr Biol 114: 53-60

46. Trube G, Rorsman P, Ohno-Shosaku T (1986) Opposite effects of tolbutamide and diazoxide on the ATP-dependent $\mathrm{K}^{+}$channel in mouse pancreatic B-cells. Pflügers Arch 407: 493-499

47. Dunne MJ, Illot MC, Petersen OH (1987) Interaction of diazoxide, tolbutamide and ATP4- on nucleotide-dependent $\mathrm{K}^{+}$channels in an insulin-secreting cell line. $\mathrm{J}$ Membr Biol 99: 215-224

48. Dunne MJ, Yule DI, Gallacher DV, Petersen OH (1989) Cromakalim (BRL 34915) and diazoxide activate ATPregulated potassium channels in insulin-secreting cells. Pflügers Arch 414:S154-S155

49. Arkhammer P, Hallberg A, Kindmark H, Nilsson T, Rorsman P, Berggren P-O (1990) Extracellular ATP increases cytoplasmic free $\mathrm{Ca}^{2+}$ concentration in clonal insulin-producing RINm5F cells. Biochem J 265: 203-211

50. Wollheim CB, Pozzan T (1984) Correlation between cytosolic free $\mathrm{Ca}^{2+}$ and insulin release in an insulin-secreting cell line. J Biol Chem 259: 2262-2267

51. Fadda GZ, Hajjar SM, Zhou X-J, Massry SG (1992) Verapamil corrects abnormal metabolism of pancreatic islets and insulin secretion in phosphate depletion. Endocrinology 130: 193-202

52. Plasman PO, Herchuelz A, Lebrun P (1991) Dual effect of 1.4-dihydropyridines on $\mathrm{Ca}^{2+}$ inflow into rat pancreatic islet cells. Naunyn Schmiedebergs Arch Pharmacol 343: 90-95

53. Mulsch A, Luckhoff A, Pohl U, Busse R, Bassenge E (1989) LY 83583 (6-anilino-5,8-quinolinedione) blocks nitrovasodilator-induced cyclic GMP increases and inhibition of platelet activation. Naunyn Schmiedebergs Arch Pharmacol 340: 119-125 
54. Luckhoff A, Pohl U, Mulsch A, Busse R (1988) Differential role of extra- and intracellular calcium in the release of EDRF and prostacyclin from cultured endothelial cells. $\mathrm{Br}$ J Pharmacol 95: 189-196

55. Corbett JA, McDaniel ML (1992) Does nitric oxide mediate autoimmune destruction of B-cells? Diabetes 41: 897903

56. Jones PM, Persaud SJ, Bjaaland T, Pearson JD, Howell SL (1992) Nitric oxide is not involved in the initiation of insulin secretion from rat islets of Langerhans. Diabetologia 35: $1020-1027$

57. Laychock SG, Modica ME, Cavanaugh CT (1991) L-arginine stimulates cyclic guanosine $3{ }^{\prime}, 5^{\prime}$-monophosphate formation in rat islets of Langerhans and RINm5F insulinoma cells: evidence for L-arginine: nitric oxide synthase. Endocrinology 129: 3043-3052

58. Malaisse WJ, Plasman PO, Blachier F, Herchuelz A, Sener A (1991) Stimulus-secretion coupling of arginine-induced insulin release: significance of changes in extracellular and intracellular pH. Cell Biochem Funct 9: 1-7

59. Moncada S, Palmer RMJ, Higgs EA (1989) Biosynthesis of nitric oxide From L-arginine, a pathway for the regulation of cell function and communication. Biochem Pharmacol 38: 1709-1715

60. Sakura H, Coles B, Gummerson N, Smith PA, Ashcroft FM (1995) Cationic amino acid transporters expressed in pancreatic B-cells. Diabetologia 38 [Suppl 1]:A111 (Abstract)
61. Dhanakoti SN, Brosnan JT, Brosnan MF, Herzberg GR (1992) Net renal arginine flux in rats is not affected by dietary arginine or dietary protein intake. J Nutr 122: 1127 1134

62. Bjaaland T, Howell SL (1989) Stimulation of insulin secretion from electrically permeabilised islets of Langerhans by L-arginine. Diabetologia 32: 467 (Abstract)

63. Debuyser A, Drews G, Henquin J-C (1991) Adrenaline inhibition of insulin release: role of the repolarization of the B cell membrane. Pflügers Arch 419: 131-137

64. Corbett JA, Tilton RG, Chang K et al. (1992) Aminoguanidine, a novel inhibitor of nitric oxide formation, prevents diabetic vascular dysfunction. Diabetes 41: 552-556

65. Welsh N, Eizirik D, Bendtzen K, Sandler S (1991) Interleukin-1 $\beta$-induced nitric oxide production in isolated rat pancreatic islets requires gene transcription and may lead to inhibition of the Krebs cycle enzyme aconitase. Endocrinology 129: 3167-3173

66. Panagiotidis G, Alm P, Lundquist I (1992) Inhibition of islet nitric oxide synthase increases arginine-induced insulin release. Eur J Pharmacol 229: 277-278

67. Sener A, Owen A, Malaisse-Lagae F, Malaisse WJ (1989) Stimulus-secretion coupling of arginine-induced insulin release. Res Commun Chem Pathol Pharmacol 65: 65-80 